\title{
Physical Performance Predictors of Success in Special Forces Assessment and Selection
}

\author{
Martha L. Teplitzky \\ U.S. Army Research Institute
}

\section{Personnel Utilization Technical Area \\ Paul A. Gade, Chief}

Manpower and Personnel Research Laboratory

Zita M. Simutis, Director

U.S. Army Research Institute for the Behavioral and Social Sciences

5001 Eisenhower Avenue, Alexandria, Virginia 22333-5600

Office, Deputy Chief of Staff for Personnel

Department of the Army

November 1991 